\title{
Impact of Watershed Restoration Based Agroforestry on Soil Quality in the Sub-Watershed Keduang, Wonogiri, Indonesia
}

\author{
Supriyadi ${ }^{1}$ \\ ${ }^{1}$ Climate Change and Biodiversity Research Group, Research and Development Center, Biotechnology and \\ Biodiversity, Research Institutions and Devotion to the Public, Sebelas Maret University, Indonesia \\ Correspondence: Supriyadi, Climate Change and Biodiversity Research Group, Research and Development \\ Center, Biotechnology and Biodiversity, Research Institutions and Devotion to the Public, Sebelas Maret \\ University, Indonesia. E-mail: supriyadi_uns@yahoo.com
}

Received: January 7, 2014 Accepted: October 23, 2014 Online Published: November 27, 2014

doi:10.5539/jsd.v7n6p223 URL: http://dx.doi.org/10.5539/jsd.v7n6p223

\begin{abstract}
The upper Solo Wonogiri Watersheed size of the catchment is 135,000 hectares. It is divided into six sub watershed, i.e. the Keduang, Temon, Alang, Wuryantoro, Wiroko, and Upper Solo. The fact that occur in areas upper Solo watershed the zone of distric Wonogiri Central of Java, is currently large ( $>90 \%)$ is the cultivation of seasonal crops with crops such as cassava, peanuts and not cultivation techniques cropping (Supriyadi, 2007). The implementation of restoration in subwatershed is one of several of cultivation system method that consider the importance of land sustainability. The objective of this research was to identify appropriate indicators for assessing the impact of longterm agroforestry systems on soil quality in areas upper Solo watershed the zone of distric Wonogiri Central of Java, Indonesia. The research was based on descriptive explorative through land surveys, while to know the value of the soil quality in Keduang subwatershed takes the point sample deliberately (purposive sampling). The Soil Quality Index (SQI) is determined by collecting data on indicators that have been selected for each soil function or Minimum Data Set (MDS). Assessment of soil quality using a scoring method data on every indicator. Soil quality index for the retoration in Keduang sub-watershed were 26,67-27,78 for native forest; 24,44-25,56 for agroforestry; and 23,33-26,67 for dry land. The average value of soil quality index in native forest is 27,04 ; in agroforestry is 24,81 and dry land is 24,07 . In native forest value of soil quality is the highest than agroforestry and dry land. The result showed that according to soil quality index, the types of management of landuse could improve soil quality. The better the soil quality, the higher the SQI. Land utiliser foe native forest had better soil quality than agroforestry and dry land, while land utilised for dry land had significant different compossed to the agroforestry system.
\end{abstract}

Keyword: Soil quality, restoration, watershed

\section{Introduction}

Soil restoration (SR) is the technique used to enhance and restore soils by physical treatment and a mixture of additives, such as compost, in an area where soil has been suffering from degradation. Soil media restoration increases the water retention capacity, reduces erosion, increases porosity, improves the soil structure and supplies nutrients to plants. It includes biological (worms) and mechanical aeration, mechanical loosening (tilling), planting dense vegetation, and applying soil amendments. Soil amendments involve the spreading and mixing of mature compost into disturbed and compacted urban soils. SR also use to reestablish the soil's long term capacity for infiltration and enhance the vitality of the soil as it hosts all manner of microbes and plant root system in the complex and symbiotic relationship.

The upper Solo (Wonogiri) Watersheed size of the catchment is 135,000 hectares. It is divided into six sub watershed, i.e. the Keduang, Temon, Alang, Wuryantoro, Wiroko, and Upper Solo. The hydrological characteristics in the catchment area of Gadjah Mungkur Dam has been monitored by BTPDAS (Balai Penelitian Teknologi Kehutanan Pengelolaan Daerah Aliran Sungai) Surakarta in outlet of four rivers entering the Dam i.e. Wuryantoro, Alang, Temon, and Keduang watershed. The results show that average of sedimentation rate in the watershed is $21 \mathrm{ton} / \mathrm{ha} / \mathrm{yr}$. However, Keduang sub catchment has produced $97 \mathrm{ton} / \mathrm{ha} / \mathrm{yr}$ sediment in 2000 . The sedimentation rate tends to decrease after 1991. Unfortunately, in 1998 the sedimentation rate tends to increase. This condition should be anticipated by concerning institution. Increasing pressure on the land in upper Solo 
Watershed due to poverty is a major driver of global change. It leads to accelerated habitat modification. Although it is not apparent to the naked eye, soil is one of the most complex habitats.

The fact that occur in areas upper Solo watershed the zone of distric Wonogiri Central of Java, is currently large $(>90 \%)$ is the cultivation of seasonal crops with crops such as cassava, peanuts and not cultivation techniques cropping (Supriyadi, 2007). Long term cultivation of land in the upper Solo sub-watershed has been resulted in degradation of soil quality that can affect of economic development in the region, if sustainable production practices are not applied. Rapid land in upper Solo Subwatershed exploitations can cause land degradation, and eventually may cause the global climate change, because of that, the balance of the land sustainability must be kept as well.

The implementation of restoration in the sub-watershed is one of several cultivation system methods that consider the importance of land sustainability. Natural resources such as vegetation, soil, and water have important roles in the suitable development of a watershed. It is therefore important to ensure the use of those natural resources in a way that the following generations will be able to profit from their advantages. Activities like land rehabilitation and soil conservation practices can prevent further environmental damages, such as severe soil erosion, and the decreasing of soil productivity through degradation of the soil's physical, chemical and biology qualities. Floods during the rain season and drought in the dry season on the lower part of the watershed, sedimentation in reservoirs and lakes, and siltation in irrigation network, as well as Doran et al. (1994) show that one centimeter top soil formation takes about 100-400 years. Therefore, soil conservation efforts on the land in the upper sub-watershed have to be conducted to ensure the sustainability of land productivity.

The agroforestry system is a solution for the development of agriculture in the sub- watershed not only to get the benefit but also for crop production while preserving the environment in order to stay healthy, on a local, regional and global levels. Agroforestry is a system of land use (farming) that combines trees with agricultural crops to increase profits, both economically and environmentally. Agroforestry systems have been believed by most people as an effective way to restore the soil fertility and prevent erosion in the upper watershed. Van Schaik \& Van Noordwijk (2002) add that an agroforestry system can be a source of farmers income and at the same time maintain environmental servicesas well as maintain the biodiversity. An increase in the diversity of plants in the field will increase the efficiency of nutrient utilization for each species: the mixed system would complement each other in nutrient utilization. Species that are rooted in the soil willact as a "safety net", and capture nutrients moving down through the soil profile, and return to the ground via avalanches litter (Cadish et al., 2004). Some species of trees in agroforestry systems have the potential to explore nutrients unattainable by root crops, to capture nutrients to move down and laterally into the soil profile and dissolving unavailable nutrition for plants (Buresh et al., 2004).

Where as agroforestry systems remain productive for long periods, yields tend to decrease the last few years. This drop in the agroforestry system productivity is traditionally attributed to the natural aging of the plants, although there is some speculation that it may also reflect a loss of soil quality. Degradation of soil quality is often associated with intensive land use types. In addition, the quality of the soil could affect plant growth and productivity, so stability of the system is expected to be affected by any soil degradation. An evaluation of the soil quality changes in long-term agroforestry systems showed that this could help to enhance the sustainability of land productivity in upper Solo watershed.

Soil quality definitions currently follow two concepts (Karlen et al., 1997; Seybold et al., 1997). The first is the "capacity of the soil to function" (Doran \& Parkin, 1994). The second is "fitness for use" (Pierce \& Larson, 1993). "Capacity of the soil to function" refers to the inherent properties of soil formation, which include climate, topography, vegetation, and parent material.

A short and comprehensive definition of soil quality has been proposed by Doran and Parkin (1994): "The capacity of a soil to function within ecosystem boundaries to sustain biological productivity, maintain environmental quality, and promote plant and animal health". The presently applied definition of soil fertility for legislation purposed in Switzerland is more detailed, but contains basically the same components. A more detailed definition of soil quality and of the factors that define it is very difficult to achieve and a large number of such definitions has been proposed (Patzel et al., 2000).

Characterization of soil quality may be approached by means of physical, chemical, or bilogy methods depending on the particular functional aspect of the soil under consideration. All three approaches detect spesific soil characteristics as well as possible interactions and thus can reflect changes in soil quality. Soil quality assessment is often used for monitoring the effect of managemen system on the capacity of soil to eor specific fappropriately funcion. This requires relevan and realiable indicator functions under given agro-climatic and socio-economic circumstances (Bucher, 2002)

Research on soil quality (SQ) was initiated to address the issues of environmental protection and food quality in industrialised countries, and to increase agriculture productivity to tackle poverty and food security problem and reduce 
land degradation in developing countries (Schjonning et al., 2004). Soil quality is often refferred to in soil science literature as the capacity of soil to functio $\mathrm{n}$ within natural or managed ecosystem boundaries to sustain plant and animal productivity, maintain or enhance water and air quality, and support human health and habitation (Larson \& Pierce, 1994). It is a holistic concept recognising soil as part of a dinamic and diverse production system with biological, chemical, and physical attributes (Sanchez et al., 2003). Soil quality is related to the concept os soil capability, which is a old human civilisation it self (Carter et al., 2004).

There has been an interest in soil and land quality from the beginning of agriculture (Carter et al., 2004) and many people araoubd the world intutively understand and use the concept to improve their soil management practised (Karlen et al., 2003). However, the concept was formally initiated when Alexander (1971) suggested developing "SQ criteria" in reference to agriculture's role in environmental improvement. Subsequently, Warkentin and Fletcher (1977) introduced concept at an international seminar on soil environment and fertility management for intensive agriculture. In its current contex, the complexity of soil and its multiple functions have been recognised, as opposed to the traditional approaches that focus solely on productive function of soil (Swift, 1999); Sanchez et al., 2003). Soil functions as a living space, input for production, climate regulator, storage, waste and pollution controller, hydrologic and biotic enviromental function, and as archive and heritage (FAO, 1996). Each of these function requires a partient quality of land to be fulfilled.

Soil quality is an evolving idea that facilities better land use planning for sustainable utilisation of the scarce soil resource (Karlen et al., 2003). Therefore during the past decade, SQ research and education program have increased exponentially throughtout the world (Karlen et al., 2003). Because the issues of productivity and sustainability are addressed simultaneously, the SQ effort is spesially important for the 2 billion people who are malnourished and for an equal number who live below the proverty level in developing countries (Eswaran et al., 1999). The abject poverty and high rate of land degradation and desertification in Ethiophia necessitate the use of the SQ analysis in the natural resourches management research for sustainable utilisation of the resources.

The great difficulty in evaluating a soil considered as a major obstacle to the sustainable management of soil ecosystems. Science based soil quality indices may provide an ecologically based approach for land managers to make decisions that promote sustainability (Andrews \& Carrol, 2001). However, a large number of soil parameters need to be determined to evaluate soil quality properly; soil physical and chemical properties have been extensively used to asses soil quality because analysis methods are simple and available (Liu et al., 2014). Fo all indicators agreed is minimum data set (MDS) to reduce the cost of soil quality assessment. Qi et al. (2009) evaluated soil quality at a county scale and showed that using an integrated quality index and MDS method can adequately represent the total data set and save time and money. Andrews et al. (2004), the indicator groups or MDS used to indirectly measure soil function, must be sufficiently diverse to represent the chemical, biological, and physical use and management on these soil functions. Among these methods, the monitoring soil properties is a dynamic method are very important because properties the soil is always in a state of flux as they respond to management and environmental forces (Pierce \& Larson, 1994). The objective of this research is to identify appropriate soil indicators to assess the impact of long-term agroforestry systems on soil quality in the Upper Solo zone Winton district in Central Java, Indonesia.

\section{Materials and Methods}

\subsection{Study Location}

The research was done in the sub-watershed of Keduang river basin of Wonogiri Central of Java province, conducted during 2011-2012. This sub-watershed has produced sediment a 97 ton/ha/yr the largest area in upper Bengawan Solo river watershed. The research area is geographically located at $7^{\circ} 42^{\prime} 29^{\prime \prime}-7^{\circ} 55^{\prime} 39^{\prime \prime}$ South Latitude and $4^{\circ} 11^{\prime} 01^{\prime \prime}-4^{\circ} 24^{\prime} 54^{\prime \prime}$ East Longitude and the total area is 35.999 ha. The slope of the site is gentle and approximately $10-15 \%$. The study soils are clayey with clay contents as high as 42 to $46 \%$ in the surface layer and increasing with depth. The soils are moderately deep with little mixing of stones in the surface horizons. The typical reddish yellow color is an indication that oxidizing conditions predominate, with $\mathrm{Fe}$ - and $\mathrm{Al}$ - oxides being the most abundant elements.

\subsection{Soil Sampling}

The research was conducted descriptive explorative through land surveys, while to know the value of the soil quality in Keduang sub-watershed takes the point sample deliberately (purposive sampling). The location of soil samples was determined by the plot model (with overlay of land use maps, geology maps, soil maps, geography maps, and rain fall maps) follow the direction of the soil fertility with three sample points in the direction of the slope (toposequen). The slope is representing the top, the middle and the bottom. In this study, there are ninelocations for soil samples. These methods are often used to determine the degree of soil degradation by comparing soil properties under the same or different the land use patterns. With such an approach, the field site can be selected on the basis of land use of agroforestry; that is, native forest (control), dry land and paddy soil. Each class was replicated at least three times. Each soil sample was a composite of 5 sub-sample $(0-30 \mathrm{~cm}$ soil dept $)$, collected from three girds $(10 \times 10 \mathrm{~m})$ 
within each field.

Whitin research site, 9 sampling points were selected, around these points, circular plots with a $10 \mathrm{~m}$ radius (100 $\mathrm{m}^{2}$ ) were delimeted and 5 random sub soil samples take from each point. Soil sample was collected from the 0 $30 \mathrm{~cm}$ dept using auger or trowels. The soil dept of $30 \mathrm{~cm}$ this is avarage depth for expansion of root (active crop rott zone). Affter collection the soil sample, all samples were placed in the airtight polyethylene bags and cool bags, and transported to the Soil Biology and Chemistry Laboratory of Agricultural Faculty of Sebelas Maret University. The arrival to the laboratory, this samples were split in two portions. This one was sieved trought a 2 $\mathrm{mm}$ mesh screen at field moisture and used for biological analysis, samples were kept at $4^{\circ} \mathrm{C}$ until the analysis were carried out, wich no longer than 2 days after soil sampling. The other samples was air-dried and future split in 2 portion. One was sieved through a $2 \mathrm{~mm}$ mesh screen for chemical analysis and other sieved through a $4 \mathrm{~mm}$ mesh screen for physical analysis.

\subsection{Selection Soil Quality Indicator}

The general criteria used for SQ Indicator in this study included of :1) sensitivey to management system, 2) precision of the measurement analysis method, 3) important and relevan to functional soil prosesses and 4) eases and cost of sampling and analysis method. Table 1 show the physical indicator as are: Soil Aggregate Stability (AGG), Bulk Density (BD), Effective soil depth and Available Water Capacity (AWC); chemical indicators as are: soil $\mathrm{pH}$, Total organic Carbon (TOC), and available $\mathrm{P}$; and biological indicators as are soil respiration $\left(\mathrm{qCO}_{2}\right)$ and Microbial Biomass Carbon (MBC). The indicators that have been selected as a set of MDS, is inexpensive meaningful for the agroforestry system. This indicators of critical soil processes such as aeration, infeltration, water retention, nutrients retention, prevention of toxic, availability of nutriens, etc., wich in relationship to soil functions such as plant production. All of the selected indicators can be measured using a composite soil sample obtained from the agroforestry system. In this study, standart scoring functions (Table 1) (Andrews et al., 2004; Qi et al., 2009) were used and scoring ranging madification between 1 and 3 were assigned. Based on indicator sensitivity of soil quality, three types of functions were applied (Leibig et al., 2001) where the best soil functionality was related with high, low and intermediate or medium values.

Table 1. Physical, chemical and biological soil quality indicator included in this study and scoring of soil quality

\begin{tabular}{|c|c|c|c|c|}
\hline \multirow{2}{*}{ Soil indicator } & \multirow{2}{*}{ Unit } & \multicolumn{3}{|c|}{ Scoring indicator } \\
\hline & & 1 (low) & 2 (medium) & 3 (high) \\
\hline $\begin{array}{l}\text { Soil Aggregate Stability (AGG) } \\
\text { (Purwowidodo, } 1992 \text { modified) }\end{array}$ & $\%$ & $0-40$ & $41-80$ & $81-100$ \\
\hline $\begin{array}{l}\text { Bulk Density (BD) } \\
\text { (Wander, et al., } 2002 \text { modified) }\end{array}$ & $\mathrm{g} / \mathrm{cm}^{3}$ & $>1,5$ & $1,2-1,-, 5$ & $<1,2$ \\
\hline $\begin{array}{l}\text { Soil pH } \\
\text { (Balittan, } 2005 \text { modified) }\end{array}$ & - & $<5$ & $5,-1-6$ & $6,1-7,3$ \\
\hline $\begin{array}{l}\text { Total Organic Carbon (TOC) } \\
\text { (Balittan, } 2006 \text { modified) }\end{array}$ & $\%$ & $<1,0$ & $1,0-5,0$ & $>5,0$ \\
\hline $\begin{array}{l}\text { Available } P \\
\text { (Balittan, } 2005 \text { modified) }\end{array}$ & $\mathrm{mg} / \mathrm{g}$ & $<5$ & $5,0-15,0$ & $>15$ \\
\hline $\begin{array}{l}\text { Available Water Capacity (AWC) } \\
\text { (Kartonegoro, B.D dan Syamsul, A.S,2006 modified) }\end{array}$ & $\%$ & $<7,62$ & $7,62-30,49$ & $>30,49$ \\
\hline $\begin{array}{l}\text { Soil Respiration (qCO2) } \\
\text { (Wander, et al., 2002) }\end{array}$ & $\mathrm{mg} \mathrm{CO} 2 \cdot \mathrm{g}^{-1} \cdot \mathrm{day}^{-1}$ & $<0,019$ & $0,019-0,132$ & $>0,132$ \\
\hline $\begin{array}{l}\text { Microbial Biomass Carbon (MBC) } \\
\text { (Wander, et al., 2002) }\end{array}$ & $\mathrm{mg} \mathrm{CO} \mathrm{CO}_{2} \mathrm{~g}^{-1}$. & $<0,019$ & $0,019-0,132$ & $>0,132$ \\
\hline Effective soil depth (SD) & $\mathrm{cm}$ & $<81$ & $81-100$ & $>100$ \\
\hline
\end{tabular}

Information: Range of skor is result modified from range of skor at curve of skor in Andrews et al. (2004). This range of skor used to integration of numbers from result analysis laboratorium. The modified with interval of skor 1-3 to easy to interpret some indicator. 
The Soil Quality Index (SQI) is determined by collecting data on indicators that have been selected for each soil function. Soil quality assessment using scoring data method on every indicator. The calculation is done by adding the soil quality scores obtained on each agroforestry system sub-watershed of Keduang. The individual index value for all the soil properties measured, are sumed to give are total Soil Quality Index (SQI) (Andrews et al., 2004), which can be described as follows:

$$
S Q i=\left(\frac{\sum_{i=1}^{n} S i}{n}\right) x 10
$$

Information:

SQI = Soil Quality Index (Soil Quality Index)

$\mathrm{Si}=$ Scores on selected indicators of land in the Minimum Data Set (MDS)

$\mathrm{n}=$ number of soil quality indicators in the MDS

Table 2. Score for soil quality indicator in agroforestry system sub-watershed of Keduang

\begin{tabular}{|c|c|c|c|c|c|c|c|c|c|}
\hline \multirow{3}{*}{ Soil Properties } & \multicolumn{9}{|c|}{ Landuse } \\
\hline & Native & Native & Native & \multirow{2}{*}{ Agroforestry } & \multirow{2}{*}{ Agroforestry } & \multirow{2}{*}{ Agroforestry } & Dry & Dry & Dry \\
\hline & Forest & Forest & Forest & & & & Land & Land & Land \\
\hline \multicolumn{10}{|l|}{ Soil Chemical Indicator } \\
\hline Total Organic Carbon & 0,55 & 1,16 & 1,35 & 1,28 & 1,46 & 1,28 & 1,68 & 1,67 & 1,34 \\
\hline Score & 3 & 3 & 2 & 2 & 2 & 2 & 2 & 2 & 2 \\
\hline Available P & 13,90 & 19,05 & 30,37 & 14,43 & 15,51 & 36,16 & 44.00 & 35,19 & 30,12 \\
\hline Score & 3 & 3 & 3 & 3 & 3 & 3 & 3 & 3 & 3 \\
\hline Soil pH & 5,4 & 5,4 & 6,1 & 5,7 & 6,0 & 5,9 & 5,7 & 5,7 & 6,0 \\
\hline Score & 2 & 2 & 2 & 2 & 2 & 2 & 2 & 2 & 2 \\
\hline \multicolumn{10}{|l|}{ Soil Physical Indicator } \\
\hline Bulk Density & 0,97 & 1,03 & 1,14 & 1,24 & 1,51 & 1,05 & 1,19 & 0,89 & 1,24 \\
\hline Score & 3 & 3 & 3 & 2 & 1 & 3 & 3 & 3 & 2 \\
\hline Available & 62,60 & 62,77 & 58,95 & 58,95 & 62,77 & 58,95 & 62,60 & 62,77 & 62,60 \\
\hline \multicolumn{10}{|l|}{ Capacity } \\
\hline Score & 3 & 3 & 3 & 3 & 3 & 3 & 3 & 3 & 3 \\
\hline Soil Aggregate Stability & 9 & 50 & 75 & 58 & 78 & 40 & 38 & 74 & 38 \\
\hline Score & 2 & 2 & 2 & 2 & 2 & 1 & 1 & 2 & 1 \\
\hline Effective soil depth & $>100$ & $>100$ & $>100$ & $>100$ & $>100$ & $81-100$ & $81-100$ & $>100$ & $81-100$ \\
\hline Score & 3 & 3 & 3 & 3 & 3 & 2 & 2 & 3 & 2 \\
\hline \multicolumn{10}{|l|}{ Soil Biologycal Indicator } \\
\hline Soil Respiration & 0,55 & 0,65 & 0,25 & 0,48 & 0,52 & 0,45 & 0,38 & 0,36 & 0,36 \\
\hline Score & 3 & 3 & 3 & 3 & 3 & 3 & 3 & 3 & 3 \\
\hline Microbial & 0,24 & 0,53 & 0,24 & 0,59 & 0,59 & 0,44 & 0,32 & 0,60 & 0,43 \\
\hline \multicolumn{10}{|l|}{ Carbon } \\
\hline Score & 3 & 3 & 3 & 3 & 3 & 3 & 3 & 3 & 3 \\
\hline$\sum$ Scoring & 24 & 24 & 25 & 23 & 22 & 22 & 22 & 24 & 21 \\
\hline SQi & 26,67 & 26,67 & 27,78 & 25,56 & 24,44 & 24,44 & 24,44 & 26,67 & 23,33 \\
\hline Mean SQi & & 27,04 & & & 24,81 & & & 24,07 & \\
\hline
\end{tabular}




\section{Result and Discussion}

Table 2 showed the scoring of indicators soil quality measured in each sampling point in agroforestry system in sub-watershed of Keduang. The SQI assessed in this research included a variety soil chemical, physics, and biological properties. Indicators of soil quality variations in soil properties associated with management practices should be distinguished for those associated with the variability of natural soils. In this research, the soil appears similar to their parent material, topography, and native vegetation, but varied in their practice management (forest and agroforesty) and the intensity of landuse.

More than half of the Keduang sub-watershed is used by four upland annual field crops: With peanut, soybean, and upland rice, which are alternately planted with corn and cassava intercrops. Base of the management landuse is grouped into three kinds of natures; forest, agroforestry, and upland annual field. In the native forest, we find trees, such as edible fern, pine, mahogany, and teak. This landuse for agroforestry is grouped into two types, based on the quality of construction in bench terraces and medium bench terraces. The comparative trees in agroforestry such as mahogany, cashew, accacia, teak and albizia are the other crops in the farm. The comparative trees, we find in upland annual fields, are cassava, corn, peanut, banana, mango, coconut, cashew, and taro.

The SQI for the retoration in the Keduang sub-watershed were $26,67-27,78$ for native forest; $24,44-25,56$ for agroforestry; and 23,33-26,67 for dry land. The average value of the SQIin native forest is 27,04; in agroforestry is 24,81 , and in dry land it is 24,07 . The native forest value of soil quality is higher than the one of agroforestry and dry land. The result showed that according to the SQI, the types of management in landuse could improve the soil quality. The better the soil quality, the higher the SQI. Land utilisers of native forest had better soil quality than those of agroforestry and dry land, while the land that was utilised as dry land dry land composition has significant differences with agroforestry system.

The balance between the productive and the environmental performance of the Keduang sub- watershed soil must be controlled on the lands to increase the monoculture production of crops, cultivation, and the application of chemical fertilizers and pesticides in the upland. Annually the fields have increased yields, however there are intensified practices, which are often associated with the loss in soil organic matter, and are referring to the criteria of soil properties by the center for soil and agroclimate research. The soil fertility area is classified as medium to high or good. The acidity of the $\mathrm{pH}$ is from high acid $(5,4)$ to near neutral $(6,1)$, with an intermediate $(13,90-44,00)$ available $\mathrm{P}$, and with an intermediate $(0,25-0,65)$ total organic carbon (TOC). The soil fertility is with the total nitrogen and available phosphorus low or very low, though the content of other mineral, such as potassium, calcium, and magnesium, is medium to high.

The soil physical property is not constraint for plant growth, there are bulk density, available water capacity, aggregate stability, and the soil depth area classified of medium to high (2-3) (Andrew, 2002).

The soil quality has biological properties that need to have the a baseline. The baseline references conditions for this study are native forests near the fields study area. The baseline comparisons truly measure the soil quality indicators, which are useful in assessing soil responds for the restoration model for soil properties with the agroforestry system and the dry land, which were contrasted with forest soils.

The results indicate the direction of change in the quantitative indicators of soil quality restoration changes in most indicators of soil quality occurs relatively quickly. The assessment of the SQI was undertaken with the totaling method. Then the Index value was multiplied by 10 to increase the value of the index in a range. The maximum value of the SQI is 27,04 if all soil properties are measured. The total SQI is then expressed as a precentage of the maximum possible value of the total SQI, for the soil properties that are measured. 


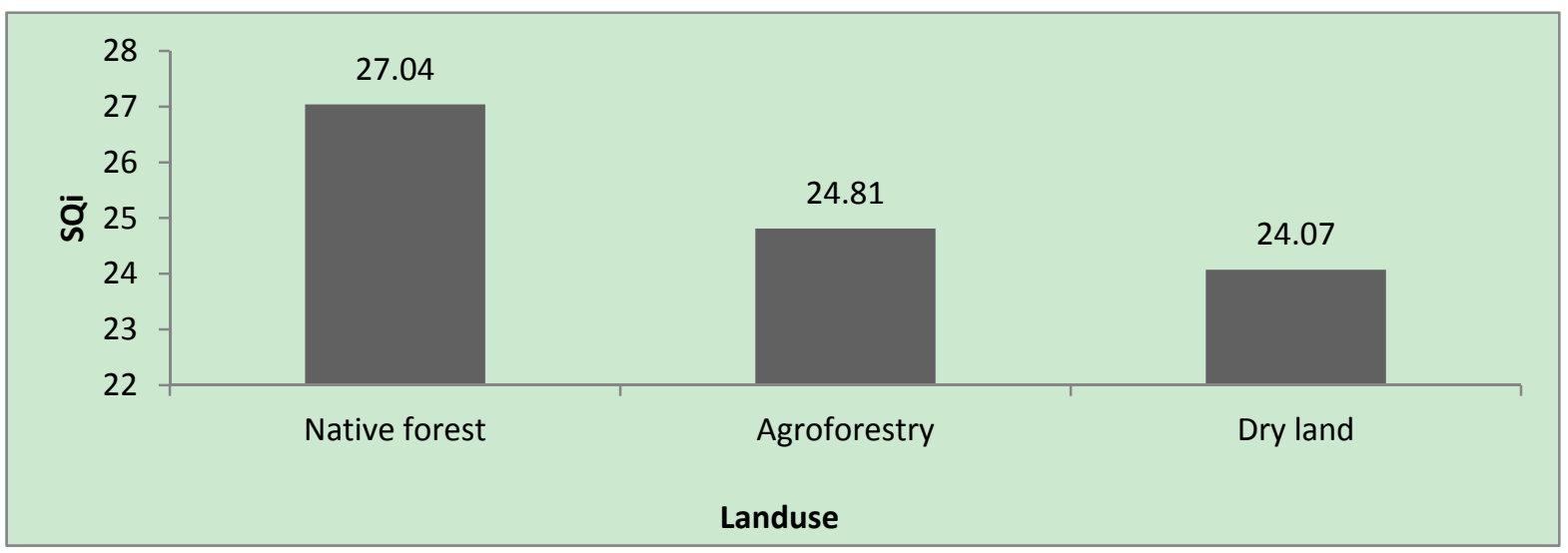

Figure 1. SQI in sub-watershed Keduang Wonogiri

The SQI is the average of the variable values category, observed in each land use. the soil quality describes the combination of physical properties, chemical, and biological causes of land capable of performing a variety of functions (Evanylo \& McGuinn, 2000). The observation (Fig. 1) showed that the land use for the native forest has the best SQI $(27,04)$ and land use for the dry land has the smallest land quality index $(24,07)$.

The calculation of the stepwise regression, indicating variables that most affect the SQI at the study site, is the depth of the soil. Soil depth is understood as a function of spatial. Deeper soil has greater land space and therefore contributes to good soil properties of physics, chemistry and biology. In most of the study area, the researchers found up to $100 \mathrm{~cm}$ soil depth. With the deepening of the soil, the soil properties can be more functional or potentially better than before deepening.

\section{Conclusion}

The restoration of the sub-watershed in Keduang river basin Wonogiri under different of agroforestry systems slightly affected of SQ indicators value of the soil. The highest SQI value $(27,78)$ obtained the management at the Keduang sub-watershed agroforestry system model at the location of nine with the composition of mango, cassava, banana, teak, groundnuts, palm oil, while the lowest SQI values (23.38) acquire management at the Keduang sub-watershed agroforestry system model at eight locations with the composition of petai china, corn, cassava, teak, sengon. Primarily through the effect on the organic matter content, which affected the aggregate stability, bulk density, available water capacity, microbial biomass and soil respiration. There should be a periodic evaluation of the soil quality in the area of the sub- watershed Keduang Wonogiri to control the quality of the soil and be aware of changes at each location, and to do better management efforts. In addition, the agro-based watershed restoration should consider the type and composition of plants and cultivation systems that do not negatively impact the soil quality, and prevent from the risk of erosion.

\section{Acknowledgements}

The authors gratefully acknowledge the financial supportet by Hibah Penelitian Unggulan 2012 Project of Sebelas Maret University, Ministry of Education and Culture of Indonesian Republic.

\section{References}

Alexander, M. (1971). Agriculture's responsibility in establishing soil quality criteria. In Environmental improvement - Agriculture's challenge in the seventies (pp. 66-71). National Academy of Sciences:Washington, DC.

Andrews, S. S., \& Carroll, R. (2001). Designing a soil quality assessment tool for sustain-able agroecosystem $\begin{array}{llll}\text { management. } & \text { Ecol. Appl., } & 11, & 1573-1585 .\end{array}$ http://dx.doi.org/10.1890/1051-0761(2001)011[1573:DASQAT]2.0.CO;2

Andrews, S. S., Karlen, D. L., \& Cambardella, C. A. (2004). The Soil Management Assessment Framework: A Quantitative Soil Quality Evaluation Method. Soil. Sci. Soc. Am. J., 68, 1945-1962. http://dx.doi.org/10.2136/sssaj2004.1945

Andrews, S. S., Karlen, D. L., \& Mitchell, J. P. (2002). A comparison of soil quality indicesmethods for vegetable production system in northern California. Agric. Ecosyst. Environ., 90, 25-45. http://dx.doi.org/10.1016/S0167-8809(01)00174-8 
Bucher, E. (2002). Soil quality characterization and remediation in relation to soil management. $\mathrm{PhD}$ thesis, Department of Crop and Soil Sciences, Pennsylvania State University, USA.

Buresh, R. J., Rowe, E. C., Livesley, S. J., Cadish, G., \& Mafongoya, P. (2004). Opportunities for Capture of Deep Soil Nutrients. In M. Van Noordwijk, G. Cadish, \& C. K. Ong (Eds.), Below-ground Interactions in Tropical Agroecosystems. Concept and Models with Multiple Plant Components (pp. 109-125). CAB Publishing. Wallingford, UK. http://dx.doi.org/10.1079/9780851996738.0109

Cadish, G., Wiligen, P., Suprayogo, D., Mobbs, D. C., van Noordwijk, M., \& Rowe, E. C. (2004). Catching and Competing for Mobile Nutrient in Soils. In M. Van Noordwijk, G. Cadish, \& C. K. Ong (Eds.), Below-ground Interactions in Tropical Agroecosystems. Concept and Models with Multiple Plant Components (pp. 171-191). CAB Publishing. Wallingford, UK. http://dx.doi.org/10.1079/9780851996738.0171

Carter, M. R., Andrews, S. S., \& Drinkwater, L. E. (2004) Systems approaches for improving soil quality. In P. Schjonning, S. Elmholt, \& B. T. Christensen (Eds.), Managing soil quality: challenges (pp. 261-281).

Doran, J. W., \& Parkin, T. B. (1994). Defining and Assessing Soil Quality. In J. W. Doran, D. C. Coleman, D. F. Bezdicek, \& B. A. Stewart (Eds.), Defining Soil Quality for a Sustainable Enviroment (pp. 3-23). SSSA Special Publication.

Eswaran, H., Beinroth, F. H., Reich, P. F., \& Quandt, L. A. (1999). Guy D. Smith Memorial slide collection. Vertisols: Their properties, classification, distribution and management. USDA Natural Resources Conservation Service. Retrieved January 15, 2004, from http://www.nrcs.usda.gov/technical/worldsoils

Evanylo, G., \& McGuinn, R. (2000). Agricultural Management Practices and Soil Quality: Measuring, assessing, and comparing laboratory and field test kit indicators of soil quality attributes. Virginia Cooperative Extension Publication Number 452-400. Retrieved January 28, 2003, from http://www.ext.vt.edu/pubs/compost/452-400/452-400.html

FAO. (1996). Land quality indicators and their use in sustainable agriculture and rural development. In Proceedings of the Workshop organized by the Land and Water Development Division, FAO Agriculture Department and the Research, Extension and Training Division, FAO Sustainable Development Department (pp. 2526). FAO: Rome.

Karlen, D. L., Andrews, S. S., Wienhold, B. J., \& Doran, J. W. (2003). Soil quality: Humankind's foundation for survival. J. Soil Water Conserv., 58, 171-179.

Karlen, D. L., Mausbach, M. J., Doran, J. W., Cline, R. G., Harris, R. F., \& Schuman, G. E. (1997). Soil Quality: a concept, definition and framework for evaluation. Soil Sci. Soc. Am. J., 61, 4-10. http://dx.doi.org/10.2136/sssaj1997.03615995006100010001x

Larson, W. E., \& Pierce, F. J. (1994). The dynamics of soil quality as a measure of sustainable management. In J. W. Doran, D. C. Coleman, D. F. Bezdicek, \& B. A. Stewart (Eds.), Defining Soil Quality for a Sustainable Enviroment (pp. 37-70). SSSA Special Publication. Winconsin.

Liebig, M. A., Varvel, G. E., \& Doran, J. W. (2001). A simple performance-based index forassessing multiple agroecosystem functions. Agron. J., 93, 313-318. http://dx.doi.org/10.2134/agronj2001.932313x

Liu, Z., Zhou, W., Shen, J., Li, S., Liang, G., Wang, X., \& Ai, C. (2014). Soil Quality Assessment of Acid Sulfate Paddy Soils with Different Productivities in Guangdong Province, China. Journal of Integrative Agriculture, 13(1), 177-186. http://dx.doi.org/10.1016/S2095-3119(13)60594-8

Patzel, N., Sticher, H., \& Karlen, D. L. (2000). Soil Fertility — Phenomenon and Concept. J. Plant Nutr. Soil Sci., $163,129-142$.

Pierce, F. J., \& Larson, W. E. (1993). Developing criteria to evaluate sustainable land management. In J. M. Kimble (Ed.), Proceedings of the Eighth International Soil Management Workshop: Utilization of Soil survey Information for Sustainable Land Use (pp. 7-14). USDA Soil Conservation Service, National Soil Survey Center, Lincoln, NE.

Pierce, F. J., \& Larson, W. E. (1994). Developing Criteria to Evaluate Sustainable Land Management. Proceeding of the Eighth International Soil Management Workshop: Ultilization of Soil Survey Information for Sustainable. International Workshop (8th: 1992-1993: Oregon): 7-14.

Qi, Y. B., Darilek, J. L., Huang, B., Zhao, Y. C., Sun, W. X., \& Gu, Z. Q. (2009). Evaluating soil quality indices in an agricultural region of Jiangsu Province, China. Geoderma, 149, 325-334. http://dx.doi.org/10.1016/j.geoderma.2008.12.015 
Sanchez, P. A., Palm, C. A., \& Buol, S. W. (2003). Fertility capability soil classification: a tool to help assess soil quality in the tropics. In 'The assessment of soil quality'. (Eds G Sposito, A Zabel). International Journal of Soil Science, 114, 157-186.

Schjonning, P., Elmholt, S., \& Christensen, B. T. (2004). Soil quality management concepts and terms. In P. S. Schjonning, S. Elmholt, \& B. T. Christensen (Eds.), Managing soil quality challenges in modern agriculture (pp. 1-15). CABI Publishing. http://dx.doi.org/10.1079/9780851996714.0001

Seybold, C. A., Mausbach, M. J., Karlen, D. L., \& Rogers, H. H. (1996). Quantification of soil quality. In The Soil Quality Institude (Ed.), The Soil Quality Concept. USA: USDA Natural Resources Conservation Service.

Supriyadi. (2007). Tim Ekologi. Ekspedisi Bengawan Solo. Kompas.

Swift, M. J. (1999). Integrating soils, systems and society. Nature and Resources, 35(4).

Van Schaik, C. P., \& Van Noordwijk, M. (2002). Agroforestry and biodiversity: Are they compatible? In S. M. Sitompul, \& S. R. Utami (Eds.), Akar pertanian sehat, Konsep dan pemikiran. Rangkuman makalah pemerhati pertanian sehat (pp. 37-48). Jurusan tanah Unibraw.

Warkentin, B. P., \& Fletcher, H. F. (1977). Soil quality for intensive agriculture. In Intensive agriculture. Proceedings of the International Seminar on Soil Environment and Fertility Management (pp. 594-598). Society of Soil Science and Manure, National Institute of Agriculture Science: Tokylu.

\section{Copyrights}

Copyright for this article is retained by the author(s), with first publication rights granted to the journal.

This is an open-access article distributed under the terms and conditions of the Creative Commons Attribution license (http://creativecommons.org/licenses/by/3.0/). 